\title{
The Bright Side of Unionization: The Case of Stock Price Crash Risk
}

\author{
Jeong-Bon Kim \\ City University of Hong Kong \\ jeongkim@cityu.edu.hk
}

Eliza Xia Zhang

University of Washington Tacoma

zhang20@uw.edu

\author{
Kai Zhong \\ University of International Business and Economics \\ zhongkai@uibe.edu.cn
}

Current Version: May 2019 


\section{The Bright Side of Unionization: The Case of Stock Price Crash Risk}

This study examines whether and how labor unionization influences stock price crash risk. Using a regression discontinuity design that employs union elections as an exogenous shock yielding local variation in unionization, we find that unionization leads to a significant decline in stock price crash risk. We further explore the underlying mechanisms through which unionization affects crash risk and find that labor unions constrain managerial resource diversion and overinvestment, demand less risk-taking, and facilitate transparent information flow, which in turn reduces crash risk. Overall, our results suggest that unions play an important governance role. Our study sheds new light on a formerly under-researched beneficial impact of unionization and the role that organized labor plays in influencing extreme downside risk in the equity market.

Keywords: unionization, stock price crash risk, governance

\section{Introduction}

Although union membership is declining, labor unions still play a critical role in various corporate activities (e.g., Francia 2012; Kerrissey and Schofer 2013; Chen, Kacperczyk, OrtizMolina 2011). Today, unions represent more than eight million workers at the private sector in the United States, and 33 out of the largest 100 industrial firms have unionized employees (Campello, Gao, Qiu, and Zhang 2018). It is well-known that unions protect their members' interests through collective bargaining (e.g., Freeman 1980; Lewis 1986). However, little is known about their influence on downside risk at the firm level, particularly extreme negative tail risk in the equity market or simply stock price crash risk. To fill this void, our study aims to provide systematic evidence on whether and how unions influence a firm's stock price crash risk.

It is interesting and important to investigate the impact of unionization on stock price crash risk for multiple reasons. First, as an extreme, unanticipated outcome, firm-level stock price crash has potential to shed light on the true nature of unionization (Taleb 2007; Kim, Li and Zhang 2011a and 2011b), which economists have been debating for decades. Second, the effect of unions on 
crash risk could have implications for policy making, given that "unions in the United States are regulated and can be altered by labor laws and regulations over time" (Bradley, Kim, and Tian 2017, 1). Lastly, stock price crashes bring about a huge loss of investor confidence and thus have a serious impact on investor welfare. Unlike the second moment volatility risk, stock price crash risk, which is also called the third moment negative skewness risk, cannot be diversified away through portfolio diversification strategies by outside investors (Sunder 2010; Kim and Zhang 2016). It is therefore critical to understand whether and how unionization accelerates or ameliorates the likelihood of stock price crash occurrence at the firm level.

To investigate the effect of unionization on crash risk, we propose and test two competing hypotheses based on the predominant views on the economic consequences of unionization. Our first hypothesis argues that unionization reduces stock price crash risk for the following reasons. First, unions could curb managerial resource diversion and overinvestment because they have a voice in corporate governance through threat to invoke a labor strike, stakeholder activism, or equity ownership (Agrawal 2012; Faleye, Mehrotra, and Morch 2006; Leung, Li, and Rui 2009; Prevost, Rao, and Williams 2012). Second, since organized labor has a fixed claim on firms' resources, they resemble debtholders and prefer less risk taking (Chen, Kacperczyk, and OrtizMolina 2011; Chyz, Leung, Li, and Rui 2013). Third, unions may facilitate more transparent information flow in that unions can request financial information from management and gather additional information during the negotiation (Kleiner and Bouillon 1988). With fewer resource diversions, less overinvestment, less risk-taking, and more transparent information flow, stock prices are less likely to experience an abrupt, large-scale decline, i.e., stock price crashes (e.g., Kim, Li and Zhang 2011a; Hong, Kim and Welker 2017; Chen, Kim, Li, and Liang 2018; Khurana, Pereira, and Zhang 2018). We term this view the "governance hypothesis." 
An alternative hypothesis predicts that unionization increases stock price crash risk. There are at least two reasons for such an increase in crash risk. One reason is that unionization may contribute to high opacity since managers at unionized firms have an incentive to preserve high information asymmetry with outsiders to keep their bargaining advantage over labor unions (e.g., Hilary 2006; Reynolds, Masters, and Moser 1998; Scott 1994). To the extent that opacity facilitates bad-news hoarding, unionization is likely to increase stock price crash risk (Hutton, Marcus, and Tehranian 2009; Hong, Kim, and Welker 2017). Another reason is that unionization incentivizes firms to issue more debt to decrease the funds available for unionized employees and protect shareholder wealth from being expropriated by unions (e.g., Bronars and Deere 1991; Matsa 2010). More debt increases default risk, which in turn exacerbates stock price crash risk (Zhu 2016). We refer to the increase in crash risk arising from one or all of these potential effects of unionization as the "threat hypothesis."

We test the above two hypotheses by investigating whether unions increase or decrease stock price crash risk. However, it is empirically challenging to identify the effect of unionization on crash risk. First, there are no large-scale firm-level or establishment-level data on the extent of unionization readily available. Second, even if such data are available, it is difficult to identify the causal effect of unionization on crash risk due to various endogeneity concerns. Union election outcomes could be related to unobservable firm features that influence stock price crash risk at the same time (the correlated omitted variable concern). It is also possible that labor forces in firms with low crash risk are more likely to win union elections and become unionized than those with high crash risk (the reverse causality concern).

In this article, we collect firm-level union election data from the National Labor Relations Board (NLRB), which allows us to distinguish between firms that elect to be unionized and those 
that do not. To identify the causal effect of unionization on crash risk, we use a regression discontinuity design (RDD). This approach uses a locally exogenous variation in unionization produced by "union elections that pass or fail by a small margin of votes" (Bradley, Kim, and Tian 2017, 2). It compares crash risk of firms that pass elections by a small margin with those that do not. The RDD is a powerful strategy in establishing a causal relation between unionization and crash risk because, "for these close-call elections, passing is very close to an independent, random event and therefore is unlikely to be correlated with unobservable firm characteristics" (Bradley, Kim, and Tian 2017, 2). We follow prior research to capture crash risk using two measures: the negative skewness of firm-specific weekly returns and the ratio of down-week volatility to the upweek volatility (Chen, Hong and Stein 2001; Hong, Kim and Welker 2017).

After running multiple diagnostic tests to make sure that the main assumptions underlying the RDD are met, we find that unionization reduces stock price crash risk. This result is robust to alternative bandwidths and kernels and does not hold when we artificially choose thresholds that determine union election results. We further find that the impact of unionization on crash risk is significant for firms located in states without right-to-work law, but insignificant for firms in states with such a law. This is because unions have a stronger influence in states without right-to-work law. We also conduct various cross-sectional analyses to shed light on the underlying mechanisms through which unions influence crash risk. We find that the effect of unionization on crash risk is stronger among firms with more resource diversion and overinvestment, greater business and financial risk-taking, and higher opacity. These results suggest that unions constrain managerial resource diversion and overinvestment, demand less risk taking, and facilitate transparent information flow, which in turn reduces stock price crash risk. 
Our study adds to existing literature in the following ways. First, our study expands the growing literature on the determinants of stock price crash risk. For example, prior studies show that opacity boosts the risk of stock price crashes (Jin and Myers 2006; Hutton, Marcus, and Tehranian 2009; Kim and Zhang 2014; and Hong, Kim and Welker 2017), while managers' political ranks in China are inversely associated with crash risk (Chen, Kim, Li, and Liang 2018). However, prior research has paid little attention to the role of non-managerial employees in influencing crash risk. To the best of our knowledge, this study is the first to show that nonmanagerial employees, particularly unionized employees or organized labor, play a significant role in reducing crash risk.

Moreover, our study differs from prior research on stock price crash risk in that it uses the regression discontinuity design (RDD) as an identification strategy. Existing studies on the determinants of crash risk focus predominantly on the association between various factors and crash risk, which limits the ability of researchers to make causal inferences (Gow, Larker, and Reiss 2016). ${ }^{1}$ Unlike prior studies, our study is one of the few, if not the first, to adopt the RDD design which allows us to make a causal inference on the impact of organized labor on crash risk. Specifically, our analysis focuses on firms that win or lose union elections by a small margin. As such, the union election outcome in our study can be viewed as being random and unpredictable. This helps us to establish a causal relation between unionization and crash risk by effectively ruling out potential endogeneity associated therewith.

Second, our study contributes to current debates over the benefits and costs of unionization. On the negative side, the literature shows that unions help their members to earn higher wages (Freeman and Medoff 1979; Lewis 1986; Jarrell and Stanley 1990); reduce innovations (Bradley,

\footnotetext{
${ }^{1}$ A notable exception is $\mathrm{Kim}, \mathrm{Lu}$, and $\mathrm{Yu}$ (2018), who use brokerage mergers and closures as an exogenous shock leading to analyst coverage drop to examine the causal impact of analyst coverage on ex ante expected crash risk.
} 
Kim, and Tian 2017); lead to underinvestment (e.g., Connolly, Hirsch, and Hirschey 1986; Fallick and Hassett 1999; Hirsch 1992), higher cost of equity (Chen, Kacperczyk, and Ortiz-Molina 2011), lower firm profitability (e.g., Clark 1984; Cable and Machin 1991; Menezes-Filho 1997), lower equity value (e.g., Ruback and Zimmerman 1984; Lee and Mas 2012), and higher information asymmetry (e.g., Hilary 2006; Scott 1994; Reynolds, Masters, and Moser 1998). On the positive side, existing studies document that unions play a governance role (Agrawal 2012; Faleye, Mehrotra, and Morch 2006; Leung, Li, and Rui 2009; Prevost, Rao, and Williams 2012) and hence constrain tax aggressiveness (Chyz, Leung, Li, and Rui 2013); and demand firms not to undertake high-risk projects (Chen, Kacperczyk, and Ortiz-Molina 2011; Chyz, Leung, Li, and Rui 2013). This study contributes to the debate over the economic consequences of unionization by examining the role of labor unions in influencing extreme negative tail risk that is more likely to speak to the true nature of unionization (e.g., Taleb 2007). It provides novel and causal evidence on a hitherto under-researched beneficial impact of unionization by showing that organized labor contributes to lowering stock price crash risk.

Finally, our study is timely and has implications for policy makers. In his 2015 State of the Union Address, the former president Barack Obama told Congress: "We still need laws that strengthen rather than weaken unions" (Becker 2015, 65). But recently, some states have considered labor laws that significantly weaken the power of organized labor, while some states have put such laws in place. For example, in March 2013, the state of Michigan passed right-towork laws that ban a labor union's membership and financial support as prerequisites for employment. Indiana also passed similar laws a year earlier. In a widely publicized case, Boeing chose to manufacture the new Dreamliner airplane in South Carolina rather than in Washington to avoid potential interruptions from union strikes because South Carolina is a state with right-to- 
work laws, while Washington is not (Wall Street Journal 2011). Our findings of a lower crash risk after unionization should be of interest to policy makers when they change labor legislation or union regulations to increase investor welfare and stabilize the capital market, given that stock price crashes are devastating to investor confidence and wealth and capital market stability.

The remainder of the paper is organized as follows. Section 2 reviews the related literature and develops the hypothesis. Section 3 describes the sample, variable measurement, and presents the descriptive statistics. In Section 4, we report and discuss the main results. Section 5 examines the underlying mechanisms, whereas Section 6 conducts the additional analyses. The final section concludes the paper.

\section{RELATED LITERATURE AND HYPOTHESIS DEVELOPMENT}

\subsection{Labor Unions and Corporate Real Activities}

Existing literature documents that labor unions influence a variety of corporate real activities. For example, unions use their collective bargaining power to help their members earn higher wages than non-unionized employees (Freeman and Medoff 1979; Lewis 1986; Jarrell and Stanley 1990). Due to a concern about unions' rent seeking, unionized firms hold less cash (Klasa, Maxwell, and Ortiz-Molina 2009), take on more debt (Bronars and Deere 1991; Matsa 2010), and underinvest in assets (e.g., Connolly et al. 1986; Fallick and Hassett 1999; Hirsch 1992). Since unions make wages sticky and layoffs costly and regularly interfere with firms' restructurings, unions reduce firms' operational flexibility, which in turn raises firms' systematic risk and hence cost of equity (Chen, Kacperczyk, and Ortiz-Molina 2011). Unionization is also associated with lower firm profitability (e.g., Clark 1984; Cable and Machin 1991; Menezes-Filho 1997) and lower equity value (e.g., Ruback and Zimmerman 1984; Lee and Mas 2012). 
However, unionization does not have an unambiguously adverse effect on a firm's real activities. Labor unions can play a governance role and influence corporate decision making through threat to withdraw their contributions to firms via work stoppages or strikes, or through stakeholder activism or equity ownership (Agrawal 2012; Faleye, Mehrotra, and Morch 2006; Leung, Li, and Rui 2009; Prevost, Rao, and Williams 2012). For instance, unionization is related to more vote-no campaigns and shareholder proposals (Ertimur, Ferri, and Muslu 2010). As representatives of unionized public employees, state pension funds directed $45 \%$ of Disney's shareholders not to vote for Michael Eisner in 2004, which led to his removal as chairman of the company's board of directors (Reilly 2005). The monitoring role of labor unions constrains managers' tax aggressiveness (Chyz, Leung, Li, and Rui 2013). In addition, unions prefer firms to undertake less risky investment; organized labor resembles risky debtholders in that they have a fixed claim on the firm and are more concerned about downside risk rather than upside potential (Chen, Kacperczyk, and Ortiz-Molina 2011; Chyz, Leung, Li, and Rui 2013).

\subsection{Labor Unions and Corporate Disclosures}

Unionization can result in an opaque information environment because managers at unionized firms have an incentive to keep high information asymmetry with outsiders due to their concern that disclosure transparency may undermine their position in collective bargaining (Hilary 2006). Using a sample of Canadian firms, Scott (1994) finds less voluntary disclosures of an important piece of information in union negotiation such as information about pension plans, when union strikes are approaching. Reynolds, Masters, and Moser (1998) state that both managers and unions attempt to hide or misstate their positions in negotiation process to obtain a stronger bargaining power. In a related vein, several studies find that unionized firms engage more in downward earnings management to strengthen their bargaining position, when labor negotiations 
are approaching or after the unionization (e.g., DeAngelo and DeAngelo 1991; Cullinan and Knoblett 1994; Bowen, DuCharme, and Shores 1995; D’Souza, Jacob, and Ramesh 2000). Recent studies also show that to preserve the information asymmetry between inside managers and organized labor, unionized firms prefer private loans to public bonds (Cheng 2017), pay lower audit fees and are less likely to hire high-quality auditors such as Big 4 or industry-specialist auditors (Cheng, Mitra, Song 2017).

On the other hand, unionization may facilitate more transparent information flow, leading to lower information asymmetry between unions and managers. Kleiner and Bouillon (1988) argue that unionized employees may gain privileged access to a significant amount of information about the firm even if the firm does not disclose such information. They also point out that unions can request financial information from management and gather additional information during negotiations. If firms are reluctant to share the information that unions request, unions can petition with NLRB or sue (Robbins 1994).

\subsection{Hypothesis Development}

Unionization could affect stock price crash risk via its effect on the real activities and that on the information flow. When it comes to the real activities, unionization could constrain managerial resource diversion and overinvestment due to its monitoring role. Unions may have a voice in corporate governance and influence corporate decision making through threat to withdraw the contributions to firms, stakeholder activism, or equity ownership (e.g., Agrawal 2012; Faleye, Mehrotra, and Morch 2006; Prevost, Rao, and Williams 2012). Thus, unions have potential to curb managerial resource diversion and overinvestment since these activities reduce the resources available to unionized employees and even threaten the survival of the firm. With fewer resource diversions and overinvestments, stock prices are less likely to crash since these two activities, if 
unconstrained, could eventually lead to a large-scale abrupt decline in stock prices (Kim, Li and Zhang 2011a; Hong, Kim and Welker 2017; Khurana, Pereira and Zhang 2018).

Unionization can also influence crash risk through its impact on risk taking. Unions prefer firms to take fewer risks because similar to creditors, organized labor has a fixed claim on firms' resources in the form of wages and salaries (Chen, Kacperczyk, and Ortiz-Molina 2011; Chyz, Leung, Li, and Rui 2013). Faleye, Mehrotra, and Morch (2006) document that employee equity ownership is related to lower business risk, while Simintzi, Vig, and Volpin (2015) show that union density is associated with lower leverage, which reduces financial risk. ${ }^{2}$ As firms take fewer risks, their stock prices are less likely to tumble. Some regulators and academics point out that excessive risk taking stemming from stock options leads to the recent financial crisis (e.g., Bebchuk 2009). Recently, Chen, Kim, Li, and Liang (2018) find that in China, managers at high political ranks are associated with lower crash risk than those at low ranks. This is because the former employs fewer risky strategies than the latter to stay employed in China's closed pyramidal managerial labor market where opportunities for alternative employments are limited for managers with higher political ranks.

Additionally, unionization could affect crash risk through its effect on the information flow. Employees in a unionized firm may attain a significant amount of information about the firm even if the firm does not release such information, and unions can gather additional information in the negotiating process (Kleiner and Bouillon 1988). Further, unions may empower employees to do whistle-blowing, which constrains managers to hide information or allows the information hidden by management released to the public. With more transparent information flow for unionized firms, it is less likely that bad news will be concealed, which in turn reduces stock price

\footnotetext{
${ }^{2}$ Union density reflects the degree of labor bargaining centralization and is captured by the ratio of union membership divided by employment.
} 
crash risk given that bad-news hoarding leads stock prices to crash (e.g., Jin and Myers 2006; Kim, Li and Zhang 2011a, 2011b).

In short, unionization may reduce stock price crash risk by constraining managerial resource diversion and overinvestment, controlling excessive risk-taking, and facilitating transparent information flow. We call this view the "governance hypothesis" and state it below in alternative form:

H1a: Unionization leads to a decrease in stock price crash risk, ceteris paribus.

Alternatively, unionization may lead to higher crash risk for at least two reasons. First, unionization may incentivize managers to preserve information asymmetry with outsiders due to the concern that information release weakens their bargaining power (e.g., Hilary 2006; Reynolds, Masters, and Moser 1998; Scott 1994). As a result, bad news is more likely to be withheld and stockpiled within a firm, which increases the likelihood of stock price crash occurrence at the firm level (e.g., Jin and Myers 2006; Kim, Li and Zhang 2011a, 2011b). Second, unionized firms take on more debt to decrease the funds available for unionized employees and protect shareholder wealth from being expropriated by unions (e.g., Bronars and Deere 1991; Matsa 2010). When firms have more debt outstanding, default risk increases, which in turn boosts stock price crash risk (Zhu 2016). We denote the rise in crash risk stemming from any one or all of these possible impacts of unionization as the "threat hypothesis." We state it below in alternative form:

H1b: Unionization leads to an increase in stock price crash risk, ceteris paribus.

\section{DATA AND VARIABLE MEASUREMENT}

\subsection{Data and Sample}


We collect data from several sources: union election data from NLRB, weekly stock return data from the Center for Research on Security Prices (CRSP), and annual financial data from Compustat. The NLRB provides detailed data related to union elections for the period 1977-2015, including the number of eligible voters, the number of voters who voted for and against unionization, the company name involved in the election, and the time and location of the election, among other things. ${ }^{3}$ But our union data start with 1980 due to the missing values of valid vote shares for unionization during 1977-1979. We follow Lee and Mas (2012) to manually match the union election data with CSRP using company names and then merge with Compustat, which gives us 5,342 elections. Next, we remove observations if election voting outcomes are missing or if less than 100 employees participate in the election, resulting in 1,037 elections. ${ }^{4,5}$ When there are multiple elections within a fiscal year, we keep the first election, consistent with Bradley, Kim and Tian (2017) and Huang, Jiang, Lie and Que (2017). This procedure leaves us 899 elections.

We next exclude firms in regulated industries with SIC code from 4900 to 4999 and financial institutions with SIC code from 6000 to 6999. We also exclude observations with negative total assets or equity value as well as those with missing values for variables used in the empirical models and require each fiscal year to have at least 26 weekly returns. This procedure yields a final sample of 687 unique union elections spanning the period 1981-2016, among which 200 elections favor unionization. ${ }^{6}$

\footnotetext{
${ }^{3}$ We downloaded electronic records of union election data for the period 1977-1999 from Thomas Holmes's website (http://users.econ.umn.edu/ holmes/data/geo_spill/) and for the period 2000-2011 from https://www.data.gov/and for the period 2011-2015 from the NLRB website.

${ }^{4}$ We require union elections to have at least 100 participating employees since union elections with a smaller group of participants are less likely to have a significant impact on firm behavior and outcomes. This type of filter is widely used in the labor union election literature (e.g., Lee and Mas 2012; Bradley et al. 2017; Huang et al 2017).

${ }^{5}$ In robustness checks, we follow Lee and Mas (2012) to use the fraction of workforce voted in the election to select the sample. Specifically, we remove observations if less than 2 percent of workforce voted in the election and find that our baseline results (untabulated) hold using this alternative sample. We also rerun the tests after removing observations if less than 3 percent (4 percent) of workforce voted and find qualitatively similar results.

${ }^{6}$ Our sample period ends in 2016 because our dependent variable is measured one year ahead of all the independent
} 


\subsection{Measurement of Firm-specific Crash Risk}

Following prior literature (e.g., Chen, Hong and Stein 2001; Kim, Li and Zhang 2011a, 2011b), we capture firm-specific crash risk using two alternative measures: the negative skewness of firm-specific weekly returns (NCSKEW) and the down-to-up volatility (DUVOL). Specifically, we first estimate the following expanded market model to calculate the firm-specific weekly returns:

$$
r_{j, t}=\alpha_{j}+\beta_{1 j} r_{m, \tau-2}+\beta_{2 j} r_{m, \tau-1}+\beta_{3 j} r_{m, \tau}+\beta_{4 j} r_{m, \tau+1}+\beta_{5 j} r_{m, \tau+2}+\varepsilon_{j, \tau}
$$

where $r_{j, t}$ is the return on stock $j$ in week $\tau$ and $r_{m, t}$ is the return on the CRSP value-weighted market return in week $\tau$. The lead and lag terms for market index are included to minimize potential problems arising from nonsynchronous trading. The firm-specific weekly return $(W)$ is then defined as $\mathrm{W}=\ln \left(1+\varepsilon_{j, t}\right)$.

To construct our first measure of crash risk, NCSKEW, we take the negative of the third moment of firm-specific weekly returns for each fiscal year and divide it by the standard deviation of firm-specific weekly returns raised to the third power. Specifically, for each firm $j$ in year $t$, NCSKEW is computed as:

$$
\operatorname{NCSKEW}_{j, t}=-\left[n(n-1)^{\frac{3}{2}} \sum W_{j, t}^{3}\right] /\left[(n-1)(n-2)\left(\sum W_{j, t}^{2}\right)^{3 / 2}\right]
$$

where $n$ is the number of firm-specific weekly returns during the fiscal year $t$, and other variables are defined as above. Higher values of NCSKEW correspond to higher crash risk.

To derive our second measure of crash risk, DUVOL, we split all the weekly return observations in our sample period into those with firm-specific weekly returns below the annual mean ("down" weeks) and those with firm-specific weekly returns above the annual mean ("up"

variables. 
weeks). We next calculate the standard deviation for each of these subsamples separately. $D U V O L$ is the natural logarithm of the ratio of the standard deviations of the down weeks to that of the up weeks defined as below:

$$
D_{U V O L_{j, t}}=\log \left\{\left(n_{u}-1\right) \sum_{D O W N} W_{j, t}^{2} /\left(n_{d}-1\right) \sum_{U P} W_{j, t}^{2}\right\}
$$

where $n_{u}\left(n_{d}\right)$ is the number of $U P(D O W N)$ weeks, and all other variables are defined as before. Higher values of DUVOL imply that a firm's stock price is more likely to crash.

\subsection{Descriptive Statistics}

Table 1 presents the descriptive statistics for union election and stock price crash risk variables. The mean value of NCSKEW (DUVOL) is $-0.048(-0.042)$ and the median value of NCSKEW (DUVOL) is -0.098 (-0.061), which are close to those reported by Khurana, Pereira and Zhang (2018). The mean (median) value of VOTE is $0.442(0.400)$ with a standard deviation of 0.210 , implying that on average $44.2 \%$ of votes are in favor of unionization. The mean of Unionization is 0.291 , implying that the unionization rate is about $29.1 \%$. The statistics of union election are comparable to those presented in prior literature (e.g., Bradley, Kim and Tian 2017; Huang, Jiang, Lie and Que 2017; He, Tian and Yang 2016; Campello, Gao, Qiu and Zhang 2018).

[Insert Table 1 here]

\section{RDD AND MAIN RESULTS}

\subsection{Empirical Strategy and Diagnostic Tests}

We follow Campello, Gao, Qiu and Zhang (2018) and Bradley, Kim and Tian (2017) to estimate the causal impact of unionization on crash risk using a regression discontinuity design (RDD). The RDD exploits local variations in the vote share of union elections by comparing crash risk between firms with closely won elections and those with closely lost elections. Close-win 
firms are unionized while close-loss firms are not unionized; yet the two groups are ex ante similar. Moreover, given the nature of the voting process, individuals or firms are unlikely to anticipate or manipulate close election outcomes (Campello, Gao, Qiu and Zhang 2018). Therefore, one can infer the causal effect of unionization on crash risk by contrasting crash risk between close winners and losers of union elections.

Specifically, we implement the RDD using two approaches: the global polynomial regression and the local linear regression. The former uses the following model:

$$
\begin{aligned}
\text { CRASH }_{t+1}= & \alpha_{l}+\tau \times \text { Unionization }_{t}+\sum_{n=1}^{p} \beta_{l n} \times\left(\text { VOTE }_{t}-0.5\right)^{n} \\
& +\sum_{n=1}^{p}\left(\beta_{r n}-\beta_{l n}\right) \times \text { Unionization }_{t} \times\left(\text { VOTE }_{t}-0.5\right)^{n}+\varepsilon_{t+1}
\end{aligned}
$$

where CRASH refers to crash risk variables (NCSKEW or DUVOL); Unionization is an indicator variable that takes the value of one if a firm is unionized and zero otherwise; VOTE is the union vote share in the election. We follow Lee and Lemieux (2010) to deduct 0.5 from VOTE so that Eq. (4) is centered around the vote share threshold 50\%. Accordingly, $\tau$ identifies the change in crash risk variables as the vote share just goes beyond $50 \%$ and provides an estimate of the effect of unionization on stock price crash risk.

The global polynomial regression uses all available data and hence provides more precise estimates. But this approach could bring in biases in estimates since it imposes a given functional form onto the association between vote shares and crash risk over a large range of data. Thus, we alternatively use the local linear regression that uses a narrow range of data surrounding the vote share cutoff of 50\%. This approach has the advantage of reducing biases stemming from the global functional form, but it has a lower statistical power owing to the smaller sample size.

The local linear regression approach is implemented using the following model: 


$$
\begin{aligned}
\text { CRASH }_{t+1}= & \alpha_{l}+\tau \times \text { Unionization }_{t}+\beta_{l} \times\left(\text { VOTE }_{t}-0.5\right) \\
& +\left(\beta_{r}-\beta_{l}\right) \times \text { Unionization }_{t} \times\left(\text { VOTE }_{t}-0.5\right)+\varepsilon_{t+1}
\end{aligned}
$$

where $0.5-\mathrm{h} \leq \operatorname{VOTE}_{t} \leq 0.5+\mathrm{h}$, and $\tau$ identifies the effect of unionization on crash risk. We estimate Eq. (5) using triangular and rectangular kernels.

The application of RDD relies on the satisfaction of two assumptions. One assumption is that the forcing variable (the number of vote shares) is not precisely manipulated by agents (voters and employers) around the known threshold (Lee and Lemieux 2010), suggesting a continuity of the distribution of the forcing variable surrounding the vote share threshold. ${ }^{7}$ The other assumption requires no discontinuity in other covariates that are related to crash risk around the same threshold. In other words, it requires firms that win or lose by a very small margin to be not significantly different across the other covariates. We next examine whether the two assumptions are satisfied.

To check the validity of the first assumption, i.e., the continuity of the vote share distribution, we follow Bradley, Kim and Tian (2017) to conduct two tests. First, we plot a histogram of the distribution of vote shares across 20 equally spaced vote share bins (with a $5.0 \%$ bin width) in Figure 1. If vote shares within a narrow window of the cutoff are manipulated by either voters or employers, we should observe a discontinuity in the vote share distribution at the $50 \%$ cutoff. Figure 1 shows continuous distribution of vote share within the narrow window around the cutoff, indicating that there is no precise manipulation at the threshold.

\section{[Insert Figure 1 here]}

Second, we adopt the method proposed by McCrary (2008) to formally test the continuity assumption of the vote share distribution. ${ }^{8}$ Figure 2 plots the density of union vote shares. It shows

\footnotetext{
${ }^{7}$ Even if the forcing variable is manipulated to some extent, an exogenous discontinuity still permits random assignment to the treatment so long as firms do not precisely control the forcing variable (Lee 2008).

${ }^{8}$ See http://emlab.berkeley.edu/ jmccrary/DCdensity/ for more detailed information about this test.
} 
that the density of vote shares is smooth and the fitted curve shows little evidence of a strong discontinuity around the $50 \%$ cutoff. The discontinuity estimate is -0.279 with a standard error of 0.251. Hence, we are not able to reject the null hypothesis of continuous density at the threshold, confirming anew that the vote shares are not precisely manipulated around the known cutoff.

[Insert Figure 2 here]

To check the validity of the second assumption, i.e., the continuity of other covariates, we test whether there are significant differences in the covariates of firms that fall in a narrow window of vote shares, $[48 \%, 52 \%]$ surrounding the $50 \%$ cutoff. Following prior research (e.g., Hutton, Marcus and Tehranian 2009; Kim, Li, and Zhang 2011a, 2011b; Khurana, Pereira and Zhang 2018), we include the following variables that have been shown to influence crash risk as the covariates: return on assets $(R O A)$, market-to-book ratio $(M B)$, firm size $(S I Z E)$, leverage $(L E V)$, de-trended share turnover (DTURN), standard deviation of firm-specific weekly returns (SIGMA), annual average of firm-specific weekly returns (RET), and the absolute value of discretionary accruals $(A B A C C)$. The appendix provides more details on the definitions of these covariates. Table 2 presents the results of this diagnostic test. It shows that all the covariates in the union election year are not significantly different between the close-win firms and the close-loss firms.

[Insert Table 2 here]

In short, the above diagnostic tests suggest that the union vote shares are not likely to be precisely manipulated by voters or employers around the $50 \%$ cutoff point. Moreover, other covariates do not exhibit a discontinuity at the threshold. Therefore, the assumptions of the RDD are met and the RDD can be used to identify the causal effect of unionization on crash risk.

\subsection{Main RDD Results}

\subsubsection{Graphic Analysis of the Outcome}


We first use graphical analysis to describe the relation between union vote shares and crash risk in the vicinity of the threshold. We split the vote share into 20 equally spaced bins and compute the conditional average of the crash risk variables for each bin. We next fit crash risk variables as $2^{\text {nd }}$-order polynomial functions of vote shares. Figure 3 shows the graph on the relation between the vote share and the crash risk variables. The upper plot presents the negative skewness (NCSKEW) and the bottom plot presents the down-to-up volatility (DUVOL). The $x$ axis is the forcing variable VOTE, the percentage of votes favoring unionization. The dots represent the mean value of crash risk variables (NCSKEW and DUVOL) for each bin. The solid line fits crash risk variables as quadratic polynomial functions of vote shares.

Figure 3 shows that both NCSKEW and DUVOL exhibit a discontinuity around the 50\% cutoff following the union elections. Within a narrow window of the cutoff point, crash risk drops significantly once union vote shares exceed the 50\% threshold, suggesting that unionization has a negative impact on crash risk.

\section{[Insert Figure 3 here]}

\subsubsection{Global Polynomial Regressions}

We next perform the regression discontinuity analysis using a global polynomial regression by estimating Eq. (4) with the polynomial order of two. ${ }^{9}$ Table 3 presents the results. Columns (1) and (2) report the results without control variables and year and industry fixed effects. ${ }^{10}$ Regardless of measures for crash risk, the coefficients on Unionization are negative and statistically significant at the 5\% level. These results indicate that unionization has a negative influence on stock price

\footnotetext{
${ }^{9}$ We initially estimate Eq. (4) using the polynomial order of one, two, three, and four, respectively. We report the results using the polynomial order of two because the Akaike information criteria (AIC) is the smallest when using this polynomial order and Lee and Lemieux (2010) suggest to select the polynomial order based on AIC. Though not tabulated, we find that the results using the polynomial order of two are the strongest.

${ }^{10}$ Specifically, we use Fama-French-12 industry fixed effects. As a sensitivity analysis, we repeat all the analyses using alternative industry fixed effects as identified by two-digit SIC, Fama-French 17 industries, and Fama-French 48 industries. Our results are qualitatively similar.
} 
crash risk. In terms of the economic magnitude, crash risk is $30.9 \%(22.7 \%)$ lower for unionized firms than for firms losing union elections, in a year after union election, when $N C S K E W$ $(D U V O L)$ is used to capture crash risk. Given that the standard deviation of NCSKEW (DUVOL) is $0.702(0.476)$, a $30.9 \%(22.7 \%)$ reduction represents $0.440(0.477)$ standard deviation reduction of $N C S K E W(D U V O L)$ after unionization for an average firm in the sample, which is economically significant.

\section{[Insert Table 3 here]}

In Columns (3) and (4), we include year and industry fixed effects. The coefficients on Unionization are still significantly negative at the 5\% level whether NCSKEW or DUVOL is used as the measure for crash risk, again consistent with H1a. To further check the robustness of our results, in Columns (5) and (6), we control for several variables that prior research finds to influence crash risk, although the covariates are not needed for the RDD (Lee and Lemieux 2010). The coefficients on Unionization remain significantly negative regardless of the measures for crash risk, providing additional support for H1a.

\subsubsection{Local Linear Regressions}

Although the global polynomial regressions have the advantage of providing more precise estimates due to the use of all union election data, it is essential to use local linear regressions because the RDD has strong local validity (Bakke and Whited 2012) and local linear estimates have rate optimality and superior bias features (Fan and Gijbeles, 1992; Hahn, Todd and Van der Klaauw 2001). Thus, we alternatively use local linear regressions in the vicinity of the $50 \%$ cutoff. Specifically, we employ both triangular and rectangular kernels to estimate Eq. (5) with the bandwidth defined as the optimal bandwidth based on Imbens and Kalyanaraman (2012). Table 4 reports the results. 
The coefficients on Unionization are significantly negative across both Columns (1) and (2) when triangular kernels are used, in line with the results from global polynomial regressions in Table 3. The magnitudes of the coefficients are also similar to those presented in Table 3. They show that crash risk is $30.1 \%$ (26.6\%) lower for unionized firms than for firms losing union elections when NCSKEW $(D U V O L)$ is used to capture crash risk. Given that the standard deviation of NCSKEW (DUVOL) is $0.702(0.476)$, a $30.1 \%(26.6 \%)$ reduction represents $0.429(0.559)$ standard deviation reduction of $\operatorname{NCSKEW}(D U V O L)$ after unionization for an average firm in the sample, which is economically significant. ${ }^{11}$ Columns (3) and (4) use rectangular kernels and report similar results (a drop of $26.0 \%$ and $27.8 \%$ for $N C S K E W$ and DUVOL, respectively). In short, the results in Section 4.2 suggest unionization leads to a decrease in stock price crash risk, supporting the governance hypothesis.

[Insert Table 4 here]

\subsection{Robustness Checks}

In this subsection, we conduct multiple sensitivity analyses to check the robustness of our RDD results. First, we check whether our results from local linear regressions are sensitive to the choice of alternative bandwidths. As pointed out by Lee and Lemieux (2010), selecting a bandwidth requires a trade-off between bias and precision. When a wider bandwidth is employed, more observations are included and hence the estimates are more precise, but this approach could bring about bias in the estimates since the linear estimation may not fit the data correctly. The

\footnotetext{
${ }^{11}$ Note that the relatively large economic magnitude could arise for two reasons. First, given that we require union elections to have at least 100 participating employees, we may have kept a sample of firms with more powerful unions, which should have bigger influence on corporate activities and hence crash risk. Second, we use observations within a narrow window of vote shares around the cutoff $50 \%$, in which the contrast between unionized firms and nonunionized firms may be more distinct. As the window around the cutoff becomes expanded, the coefficient magnitude goes down significantly as shown in Panel A of Table 5.
} 
opposite is true when a narrower bandwidth is selected. Thus, we test the robustness of our RDD results using alternative bandwidths.

Panel A of Table 5 reports the results of estimating Eq. (5) using triangular kernels with alternative bandwidths. ${ }^{12}$ The alternative bandwidths we employ include: $25 \%, 50 \%, 1.5$ times, and 2.0 times of the optimal bandwidth defined by Imbens and Kalyanaraman (2012). Across all these alternative bandwidths, the coefficients on Unionization are consistently negative and significant regardless of crash risk measures used. These findings indicate that our baseline RDD results using local linear regressions are robust to the use of alternative bandwidths.

[Insert Table 5 here]

Second, we use triangular kernels to estimate Eq. (5) after including the control variables in Table 3. As shown in Panel B of Table 5, the coefficients on Unionization remain negative and significant with their magnitude being similar to those reported in Table 4, irrespective of whether NCSKEW or DUVOL is used to proxy for crash risk, suggesting that our results are not sensitive to whether we control for the covariates or not.

Next, we perform several placebo tests to examine whether unionization still has a similar effect on crash risk if we artificially select a cutoff other than the true cutoff 50\%. Panel C of Table 5 reports the results of the placebo tests using triangular kernels. It shows that across all the artificially-chosen thresholds, $25 \%, 45 \%, 55 \%$, and $75 \%$, the coefficients on Unionization are insignificantly different from zero. The evidence suggests that our baseline RDD results are unlikely to be driven by chance.

\footnotetext{
${ }^{12}$ We use triangular kernels in all the robustness checks reported in Table 5 because the statistics literature has documented that "a triangular kernel is optimal for estimating local linear regressions at the boundary, because it puts more weight on observations closer to the cutoff point" (Bradely et al. 2017, 11). Nevertheless, we repeat all the analyses in Table 5 using rectangular kernels and find our results generally hold (untabulated for brevity).
} 
Finally, we test whether our baseline results still hold when using alternative measures of crash risk. Following Hutton, Marcus and Tehranian (2009) and Jin and Myers (2006), we alternatively use two other measures for crash risk: Crash and Down. Crash is an indicator variable that equals one if there is at least one crash week during which the firm experiences firm-specific weekly return 3.09 standard deviation below the mean of firm-specific weekly returns during a fiscal year and zero otherwise. Down is the number of the crash weeks that a firm experiences over the fiscal year. Panel D of Table 5 reports the results of estimating Eq. (5) using these alternative measures of crash risk. As shown in Panel D, we find that crash risk is $14.6 \%(15.7 \%)$ lower for unionized firms than for firms losing union elections when Crash (Down) is used to capture crash risk. The finding suggests that our RDD results are robust to using alternative measures of crash risk.

\section{UNDERLYING MECHANISMS}

We document pervasive evidence supporting the governance hypothesis. To better understand how unionization reduces crash risk, we now investigate the possible mechanisms through which unionization affects crash risk. Specifically, we explore four mechanisms: resource diversion, overinvestment, risk-taking, and opacity.

\subsection{Resource Diversion}

We first explore whether a decrease in managerial resource diversion after unionization is a possible mechanism through which unionization lowers crash risk. As discussed in Section 2, unions could constrain managerial resource diversion due to their monitoring role, which could in turn lower the likelihood of stock price crashes. The reason is that resource diversion could cause 
stock prices to tumble once the related information is released (Kim, Li and Zhang 2011a; Khurana, Pereira and Zhang 2018).

To test this mechanism, we examine whether the effect of unionization on crash risk is stronger among firms with more resource diversion than among firms with less resource diversion. Similar to Atwood and Lewellen (2015), Khurana, Pereira and Zhang (2018), and Louis and Urcan (2015), we capture resource diversion using two alternative measures: shareholder payout (Payout) and free cash flow (Free_CF). We use these two measures for the following reason: existing literature shows that inside managers have incentives to keep cash, rather than pay it out to shareholders, so that they can use firm resources for their personal benefits or investment in pet projects (DeAngelo, DeAngelo and Skinner 2009; Harford, Mansi and Maxwell 2008). We then partition the sample based on the sample median of these variables in year $t$ and examine the impact of unionization on crash risk in year $t+1$ separately for the two subsamples: (i) high versus low payout; and (ii) high versus low free cash flow. ${ }^{13}$ We run the local linear regressions using triangular kernels with the optimal bandwidth defined following Imbens and Kalyanaraman (2012). Table 6 presents the RDD results.

As shown in Panel A, we find that regardless of crash risk measures used, the coefficient on Unionization is negative and significant at 5\% level for the subsample of firms with low payout (and thus high likelihood of resource diversion), but not for the subsample with high payout. Panel B shows that for both measures of crash risk, the coefficient on Unionization is negative and significant at $5 \%$ level for the subsample of firms with high free cash flow, but not for the

\footnotetext{
${ }^{13}$ Note that Unionization and all partitioning variables are measured in year $t$. Despite this, partitioning variables should largely reflect the values before unionization because union elections, on average, occur in the middle of the year in our sample and the effect of union may not kick in immediately after election. Nevertheless, given that unions should have bigger effect for firms with more resource diversion (high overinvestment, more risk-taking, high opacity) before unionization, we alternatively use resource diversion in year $t-1$ (before unionization), rerun the cross-sectional analysis, and find largely similar results (untabulated for brevity).
} 
subsample with low free cash flow. In short, these results suggest that unionization has a large, significant effect on crash risk for firms that are more prone to engage in resource diversion, but only a small, insignificant effect on crash risk for firms that are less prone to resource diversion. These results buttress and enrich the view that a shrinkage in resource diversion following unionization is one underlying mechanism through which unionization lowers crash risk.

[Insert Table 6 here]

\subsection{Overinvestment}

A decline in overinvestment following unionization can be another mechanism through which unionization reduces crash risk. Given that unions have a voice in corporate governance, they could curb overinvestment, resulting in lower crash risk. The rationale is that if overinvestment continues for too long, it will create bubbles in the asset market, which in turn increases the likelihood of asset price crashes (Bleck and Liu 2007; Benmelech, Kandel and Veronesi 2010).

To test this mechanism, we examine whether the impact of unionization on crash risk is more pronounced for firms with high overinvestment than for firms with low overinvestment. We follow Richardson (2006) and Blaylock (2016) to measure overinvestment using the amount of unexpected investment (OVERINVEST) captured by the residual estimate from an investment expectation model. Appendix provides more details on the variable definition. We first partition the full sample based on the sample median of this variable and examine the impact of unionization on crash risk separately for the subsamples with high versus low unexpected investment. Panel A of Table 7 presents the RDD estimates for each subsample. It shows a negative and significant coefficient on Unionization, regardless of crash risk measures, for the subsample with high unexpected investment, but not for the subsample with low unexpected investment. 
To further check the robustness of the above results, we keep the subsample with positive values of unexpected investment, i.e., OVERINVEST, and then partition this subsample based on the median OVERINVEST. Panel B of Table 7 similarly shows a significantly negative coefficient on Unionization, irrespective of crash risk measures used, for the subsample of firms with high unexpected investment, but not for the subsample with low unexpected investment. The results reported in Table 7, taken together, indicate that unionization has a significantly negative effect on crash risk for firms with high overinvestment, but a negligible effect on crash risk for firms with low overinvestment. This evidence is in line with the view that a reduction in overinvestment after unionization is one plausible mechanism through which unionization mitigates the likelihood that firms experience stock price crashes in the future.

[Insert Table 7 here]

\subsection{Risk-taking}

The third mechanism we explore is risk-taking. Just like creditors, unionized employees care more about downside risk than upside potentials and prefer firms to take fewer risks since they have a fixed claim on firms' resources (Chen, Kacperczyk and Ortiz-Molina 2011; Chyz, Leung, Li and Rui 2013). With fewer risk-taking, stock prices of unionized firms are less likely to plunge.

To test this mechanism, we examine whether the effect of unionization on crash risk is stronger for firms with more risk-taking. We identify two dimensions of risk-taking, business risktaking and financial risk-taking. We capture business risk-taking using the standard deviation of return on assets $\left(R O A \_S T D\right)$ and financial risk-taking using leverage $(L E V)$. We then partition the sample based on the sample median of theses variables and examine the impact of unionization on 
crash risk separately for the following subsamples: (i) high versus low ROA volatility; and (ii) high versus low leverage. Table 8 presents the RDD estimates for each subsample.

As shown in Panel A, we find that no matter how we measure crash risk, the coefficient on Unionization is negative and significant for the subsample of firms with high ROA volatility, but not for the subsample with low ROA volatility. Panel B shows that for both measures of crash risk, the coefficient on Unionization is negative and significant for the subsample of firms with high leverage, but not for the subsample with low leverage. In short, these results suggest that unionization has a significant impact on crash risk for firms with more risk-taking, but not for firms with less risk-taking, confirming that a decrease in risk-taking after unionization is an underlying mechanism through which unionization lowers crash risk.

[Insert Table 8 here]

\subsection{Opacity}

We also explore whether more transparent information flow following unionization is another mechanism through which unionization diminishes crash risk. As mentioned in Section 2, unions facilitate more transparent information flow because they can gather additional information in the negotiating process and unionized employees gain access to more information about the firm even if the firm does not disclose such information (Kleiner and Bouilllon 1988). As a result, unionized firms are less likely to withhold bad news inside the firms and accumulate it over time, which in turn lowers crash risk given that bad-news hoarding contributes to stock price crashes (e.g., Jin and Myers 2006; Kim, Li and Zhang2011a, 2011b).

To test this mechanism, we examine whether the effect of unionization on crash risk is stronger for more opaque firms. We use two alternative measures of opacity: total accruals (TA) and the number of analysts following a firm (Analyst_COV). We next partition the sample based 
on the sample median of these variables and estimate our RDD regressions separately for the following subsamples: (i) high versus low total accruals; and (ii) high versus low analyst coverage. Table 9 presents the RDD estimates for each subsample.

Panel A shows that no matter how we measure crash risk, the coefficient on Unionization is negative and significant for the subsample of firms with high total accruals, but not for the subsample with low total accruals. Panel B shows that regardless of crash risk measures used, the coefficient on Unionization is significantly negative for the subsample of firms with low analyst coverage, but not for the subsample with high analyst coverage. In short, these results suggest that unionization has a significant impact on crash risk for opaque firms (with high total accruals and low analyst coverage), but not for transparent firms, supporting that transparent information flow after unionization is one economic mechanism through which unionization lowers crash risk.

[Insert Table 9 here]

\section{ADDITIONAL ANALYSES}

\subsection{Right-to-Work Legislation}

Our results thus far suggest that unions have a voice in corporate governance and hence they can constrain managerial resource diversion, curb overinvestment, request fewer risk-taking, and facilitate transparent information flow, which in turn reduces crash risk. An important assumption underlying our analysis is that unions have considerable bargaining power. To further support our story, we investigate whether the impact of unionization on crash risk varies with unions' bargaining power by taking advantage of right-to-work laws. Unions have weaker bargaining power in states that have passed right-to-work laws than in states without such laws because unions in the former states cannot set union membership and dues as prerequisites for 
employment (e.g., Bradley, Kim and Tian 2017; Campello, Gao, Qiu and Zhang 2018). As a result, unions in such states with right-to-work legislations are expected to have lower bargaining power, and thus have a weaker impact on crash risk than those in in states without such legislation. We test this prediction using the local linear regressions.

Table 10 presents the RDD results. In states with right-to-work laws, the coefficient on Unionization is insignificantly different from zero. In contrast, the coefficient on Unionization is significantly negative in states without right-to-work laws. In short, the effect of unionization on crash risk is weaker in such states that have adopted right-to-work laws due to unions' undermined bargaining power, irrespective of crash risk measures used. These results lend further support to our governance hypothesis.

[Insert Table 10 here]

\subsection{Subsample Analyses Based on Performance}

To further corroborate the governance hypothesis, we examine whether the impact of unionization on crash risk varies with firm performance. Given unions' concern for members' job security, wages, and benefits, unions should be more active in corporate governance when firm performance is poor. Hence, we expect the impact of unionization on crash risk is more pronounced among firms with poor (or low) performance than among firms with good (or high) performance. To test this conjecture, we partition the sample based on the sample median of $R O A$ and examine the impact of unionization on crash risk separately for the subsamples with good versus poor performance using local linear regressions.

Table 11 presents the RDD estimates. Across both measures of crash risk, the coefficient on Unionization is highly significant and negative for the subsample of firms with poor performance, but insignificantly different from zero for the subsample with good performance. 
This finding implies that unionization significantly reduces crash risk for firms with poor performance, but has a negligible effect on crash risk for firms with good performance, which is again in line with the governance hypothesis.

[Insert Table 11 here]

\section{CONCLUSION}

We examine the effect of unionization on stock price crash risk. Using a regression discontinuity design as an identification strategy, we find that stock price crash risk decreases significantly following unionization. We perform a battery of sensitivity analyses and find that our results still hold. We also show that the impact of unionization on crash risk is significant for firms in states without right-to-work legislation, but insignificant for firms in states with such a legislation due to unions' weaker bargaining power in these states. Our various cross-sectional analyses show that the effect of unionization on crash risk is stronger among firms with more resource diversion and overinvestment, greater business and financial risk-taking, and higher opacity. These results suggest that a reduction in managerial resource diversion, overinvestment, and risk-taking, and an increase in transparency are the underlying mechanisms through which unionization lowers crash risk.

Overall, our study sheds new light on a formerly under-researched beneficial impact of unionization. It also highlights the important role that organized labor plays in influencing crash risk, which has been largely ignored in the literature. Our results of a lower crash risk following unionization should be of interest to policy makers when they change labor legislation or union regulations to increase investor welfare and stabilize the capital market since stock price crashes are destructive to investor confidence, shareholder wealth, and capital market stability. 
Finally, we acknowledge the limitations of the RDD and alert readers to be cautious when generalizing our inferences in different contexts. The RDD exploits the local variation in unionization generated by union elections and compares crash risk between the two distinct samples of firms with the close-win and close-loss elections. Thus, it can have strong local validity, but weak external validity. In other words, the negative impact of unionization on crash risk may be only applicable to firms with vote shares falling in the close vicinity of the threshold. It should be noted, however, that in the presence of heterogeneous treatment effect, the RDD estimate can be interpreted as a weighted average treatment effect across all individuals, where the weights are proportional to the ex ante likelihood that the realized assignment variable will be near the threshold (Lee and Lemieux 2010). We therefore reiterate the point that "it remains the case that the treatment effect estimated using a RD design is averaged over a larger population than one would have anticipated from a purely 'cutoff' interpretation”' (Lee and Lemieux 2010, 298). 


\section{References}

Agrawal, A.K. 2012. Corporate governance objectives of labor union shareholders: Evidence from proxy voting. The Review of Financial Studies 25(1): 187-226.

Atwood, T. and Lewellen, C. (2018), The Complementarity Between Tax Avoidance and Manager Diversion: Evidence from Tax Haven Firms. Contemporary Accounting Research. Accepted Author Manuscript. doi:10.1111/1911-3846.12421

Bakke, T. and T. Whited. 2012. Threshold events and identification: A study of cash shortfalls. Journal of Finance 67(3): 1083-1111.

Bebchuk, L.A. 2009. Written testimony, hearing on compensation structures and systemic risk. Committee on Financial Services, US House of Representatives, June, 11.

Becker, C. 2015. What Should Unions Do Now? Dissent 62(4): 65-68.

Benmelech, E., E. Kandel, and P. Veronesi. 2010. Stock-based compensation and CEO (dis)incentives. Quarterly Journal of Economics 125(4): 1769-1820.

Blaylock, B. 2016. Is tax avoidance associated with economically significant rent extraction among U.S. firms? Contemporary Accounting Research 33(3): 1013-1043.

Bleck, A., and X. Liu. 2007, Market transparency and the accounting regime. Journal of Accounting Research 45(2): 229-256.

Bowen, R.M., L. DuCharme, and D. Shores. 1995. Stakeholders' implicit claims and accounting method choice. Journal of Accounting and Economics 20(3): 255-295.

Bova, F. 2013. Labor unions and management's incentive to signal a negative outlook. Contemporary Accounting Research 30(1): 14-41.

Bradley, D., I. Kim, and X. Tian. 2017. Do unions affect innovation? Management Science 63(7): 2251-2271.

Bronars, S.G., and D.R. Deere. 1991. The threat of unionization, the use of debt, and the preservation of shareholder wealth. Quarterly Journal of Economics 106(1): 231-254.

Cable, J.R., and S.J. Machin. 1991. The relationship between union wage and profitability effects. Economic Letters 37(3): 315-321.

Campello, M., J. Gao, J. Qiu, and Y. Zhang. 2018. Bankruptcy and the cost of organized labor: Evidence from union elections. Review of Financial Studies: 31(3), 980-1013.

Chen, J., H. Hong, and J. Stein. 2001. Forecasting crashes: trading volume, past returns, and conditional skewness in stock prices. Journal of Financial Economics 61(3): 345-381. 
Chen, H. J., M. Kacperczyk, , and H. Ortiz-Molina. 2011. Labor unions, operating flexibility, and the cost of equity. Journal of Financial and Quantitative Analysis 46(1): 25-58.

Chen, D., J.-B. Kim, O. Z. Li, and S. Liang. 2018. China's closed pyramidal managerial labor market and the stock price crash risk. The Accounting Review 93(3): 105-131.

Cheng, L. 2017. Organized labor and debt contracting: Firm-level evidence from collective bargaining. The Accounting Review 92(3): 57-85.

Cheng, L., S. Mitra, and H. Song. 2017. Organized Labor and Audit Fees. Accounting Horizons 31(4): 93-108.

Chyz, J.A., W.S.C. Leung, O.Z. Li, and O.M. Rui. 2013. Labor unions and tax aggressiveness. Journal of Financial Economics 108(3): 675-698.

Clark, K.B. 1984. Unionization and firm performance: The impact on profits, growth, and productivity. American Economic Review 74(5): 893-919.

Connolly, R.A., B.T. Hirsch, and M. Hirschey. 1986. Union rent seeking, intangible capital and market value of the firm. Review of Economics and Statistics 68(4): 567-577.

Cullinan, C.P., and J.A. Knoblett. 1994. Unionization and accounting policy choices: An empirical examination. Journal of Accounting and Public Policy 13(1): 49-78.

DeAngelo, H., and L. DeAngelo. 1991. Union negotiations and corporate policy. Journal of Financial Economics 30(1): 3-43.

DeAngelo, H., L. DeAngelo, and D.J. Skinner. 2009. Corporate payout policy. Foundations and Trends in Finance 3(2-3): 95-287.

D'Souza, J., J. Jacob, and K. Ramesh. 2000. The use of accounting flexibility to reduce labor renegotiation costs and manage earnings. Journal of Accounting and Economics 30(2): 187-208.

Ertimur, Y., F. Ferri, and V. Muslu. 2010. Shareholder activism and CEO pay. Review of Financial Studies 24(2): 535-592.

Faleye, O., V. Mehrotra, and R. Morck. 2006. When labor has a voice in corporate governance. Journal of Financial and Quantitative Analysis 41(3): 489-510.

Fallick, B.C., and K.A. Hassett. 1999. Investment and union certification. Journal of Labor Economics 17(3): 570-582.

Fan, J. and I. Gijbels. 1992. Variable bandwidth and local linear regression smoothers. Annals of Statistics 20(4): 2008-2036. 
Francia, P. L. 2012. "Do Unions Still Matter in U.S. Elections? Assessing Labor's Political Power and Significance." The Forum, 10 (1), article 3.

Freeman, R., 1980. Unionism and the dispersion of wages. ILR Review 34(1): 3-23.

Freeman R.B., and J.L. Medoff. 1979. The two faces of unionism. The Public Interest 57: 69-93.

Gow, I.D., D.F. Larcker, and P.C. Reiss. 2016. Causal inference in accounting research. Journal of Accounting Research 54(2): 477-523.

Hahn, J., P. Todd, and W. Van der Klaauw. 2001. Identification and estimation of treatment effects with a regression-discontinuity design. Econometrica 69(1): 201-209.

Hamm, S.J.W., B. Jung, and W. Lee. 2018. Labor unions and income smoothing. Contemporary Accounting Research 35(3): 1201-1228.

Harford, J., S.A. Mansi, and W.F. Maxwell. 2008. Corporate governance and firm cash holding in the US. Journal of Financial Economics 87(3): 535-555.

He, J., X. Tian and H. Yang. 2016. Payout policy under enhanced labor power: Evidence from a new approach, Working Paper.

Hilary, G. 2006. Organized labor and information asymmetry in the financial markets. Review of Accounting Studies 11(4): 525-548.

Hirsch, B.T. 1992. Firm investment behavior and collective bargaining strategy. Industrial Relations: A Journal of Economy and Society 31(1): 95-121.

Hong, H.A., J.-B. Kim, and M. Welker. 2017. Divergence of cash flow and voting rights, opacity, and stock price crash risk: International evidence. Journal of Accounting Research 55(5): 11671212.

Huang, Q., F. Jiang, E. Lie, and T. Que. 2017. The effect of labor unions on CEO compensation. Journal of Financial and Quantitative Analysis 52(2): 553-582.

Hutton, A.P., A.J. Marcus, and H. Tehranian. 2009. Opaque financial reports, R2, and crash risk. Journal of Financial Economics 94(1): 67-86.

Imbens, G., and K. Kalyanaraman. 2012. Optimal bandwidth choice for the regression discontinuity estimator. Review of Economic Studies 79(3): 933-959.

Jarrell S.B., and T.D. Stanley. 1990. A meta-analysis of the union-nonunion wage gap. ILR Review 44(1): 54-67.

Jin, L., and S. Myers. 2006. R2 around the world: New theory and new tests. Journal of Financial Economics 79(2): 257-292. 
Kerrissey, J., and E. Schofer. 2013. Union membership and political participation in the United States. Social Forces, 91(3): 895-928.

Khurana, I.K., R. Pereira, and E. Zhang. 2018. Is real earnings smoothing harmful? Evidence from firm-specific stock price crash risk. Contemporary Accounting Research 35(1): 558-587.

Kim, J.-B., Y. Li, and L. Zhang. 2011a. Corporate tax avoidance and stock price crash risk: firmlevel analysis. Journal of Financial Economics 100(3): 639-662.

Kim, J.-B., Y. Li, and L. Zhang. 2011b. CFOs Versus CEOs: equity incentives and crashes. Journal of Financial Economics 101(3): 713-730.

Kim, J.-B., L. Lu, and Y. Yu. 2018. Analyst Coverage and Expected Crash Risk: Evidence from Exogenous Changes in Analyst Coverage. The Accounting Review (forthcoming).

Kim, J.-B., and L. Zhang (2014), "Financial Reporting Opacity and Expected Crash Risk: Evidence from Option Implied Volatility Smirks." Contemporary Accounting Research 31 (3): 851-875.

Kim, J.-B., and L. Zhang. 2016. Accounting conservatism and stock price crash risk: Firm-level evidence. Contemporary Accounting Research 33(1): 412-441.

Klasa, S., W.F. Maxwell, and H. Ortiz-Molina. 2009. The strategic use of corporate cash holdings in collective bargaining with labor unions. Journal of Financial Economics 92(3): 421-442.

Kleiner, M.M., and M.L. Bouillon. 1988. Providing business information to production workers: Correlates of compensation and profitability. ILR Review 41(4): 605-617.

Lee, D.S. 2008. Randomized experiments from non-random selection in US House elections. Journal of Econometrics 142(2): 675-697.

Lee, D.S., and T. Lemieux. 2010. Regression discontinuity design in economics. Journal of Economic Literature 48(2): 281-355.

Lee, D.S. and A. Mas. 2012. Long-run impacts of unions on firms: New evidence from financial markets, 1961-1999. Quarterly Journal of Economics 127(1): 333-378.

Leung, W.S.C., O.Z. Li, and O.M. Rui. 2009. Labor union and accounting conservatism. Working paper. The Chinese University of Hong Kong, National University of Singapore, and China Europe International Business School.

Lewis, G. 1986. Union relative wage effects. Handbook of Labor Economics 2:1139-1181.

Louis, H. and O. Urcan. 2015. Agency conflicts, dividend payout, and the direct benefits of conservative financial reporting to equity-holders. Contemporary Accounting Research 32(2): 455-484. 
Matsa, D.A. 2010. Capital structure as a strategic variable: Evidence from collective bargaining. The Journal of Finance 65(3): 1197-1232.

McCrary, J. 2008. Manipulation of the running variable in the regression discontinuity design: A density test. Journal of Econometrics 142(2): 698-714.

Menezes-Filho, N.A. 1997. Unions and profitability over the 1980s: Some evidence on union-firm bargaining in the United Kingdom. The Economic Journal 107(442): 651-670.

Prevost, A.K., R.P. Rao, and M.A. Williams. 2012. Labor unions as shareholder activists: champions or detractors? Financial Review 47(2): 327-349.

Reilly, Christopher M., January 2005, Labor unions seek relevance on Wall Street, Labor Watch, $1-6$.

Reynolds, L.G., S.H. Masters, and C.H. Moser. 1998. Labor Economics and Labor Relations. 11th edition. Englewood Cliffs, NJ: Prentice Hall.

Richardson, S. 2006. Over-investment of free cash flow. Review of Accounting Studies 11(2-3): 159-189.

Robbins, B. 1994. Rethinking financial information disclosure under the national labor relations act. Vanderbilt Law Review 47: 1905-1937.

Ruback, R.S., and M.B. Zimmerman. 1984. Unionization and profitability: Evidence from the capital market. Journal of Political Economy 92(6): 1134-1157.

Simintzi, E., V. Vig, and P. Volpin. 2015. Labor protection and leverage. Review of Financial Studies 28(2): 561-591.

Scott, T.W. 1994. Incentives and disincentives for financial disclosure: Voluntary disclosure of defined benefit pension plan information by Canadian firms. The Accounting Review 69(1): 2643.

Sunder, S., 2010. Riding the accounting train: from crisis to crisis in eighty years. Presentation at the Conference on Financial Reporting, Auditing and Governance, Lehigh University, Bethlehem, PA.

Taleb, N., 2007. The Black Swan: The Impact of the Highly Improbable. Random House Inc., New York.

Wall Street Journal. 2011. The death of right to work. (April 21), http://www.wsj.com/articles/SB10001424052748704570704576275351993875640.

Zhu, W. 2016. Accruals and price crashes. Review of Accounting Studies 21(2): 349-399. 


Dependent variables
NCSKEW

\section{Testing variables}

Unionization An indicator variable that equals one if a firm is unionized as a result of a labor union election and zero otherwise

VOTE The total number of votes for unionization divided by the total number of eligible employees in a given union election.

\section{Control variables}

$R O A$

$M B$

SIZE

$L E V$

DTURN

SIGMA

RET

$A B A C C$
The income before extraordinary items divided by lagged total assets

The market value of equity divided by the book value of equity

The log of the market value of equity

The total long-term debt divided by total assets

The average monthly share turnover over the current fiscal year period minus the average monthly share turnover over the previous fiscal year period, where monthly share turnover is computed as the monthly trading volume divided by the total number of shares outstanding during the month

The standard deviation of firm-specific weekly returns over the fiscal year period

The mean of firm-specific weekly returns over the fiscal year period, times 100

The absolute value of discretionary accruals, where discretionary accruals are residuals obtained by estimating the modified Jones (1991) model in the cross-section by each industry (SIC 2-digit) 
year. Modified Jones (1991) model used is the following: TA/Assets $=\lambda(1 /$ Assets $)+\beta_{1}(\triangle S A L E S-\triangle A R) /$ Assets $+\beta_{2}$ (PPE/Assets), where $T A$ is total accruals, $\triangle S A L E S$ is change in sales revenue, $\triangle A R$ is the change in accounts receivable, $P P E$ is gross property and equipment.

\section{Partitioning variables}

TA Total accruals, defined as income before extraordinary items (IB) minus operating cash flow (OANCF after 1988 or IB$\Delta \mathrm{ACT}+\Delta \mathrm{CHE}+\Delta \mathrm{LCT}-\Delta \mathrm{DLC}+\mathrm{DP}$ before 1988$)$.

Analyst_COV The number of analysts that covered the firm

OVERINVEST The residual estimated from the following model:

$$
\begin{aligned}
\text { INVEST }_{t+1}= & \alpha_{0}+\alpha_{1} M B_{t}+\alpha_{2} \text { ROA }_{t}+\alpha_{3} \text { CASH }_{t}+\alpha_{4} \text { AGE }_{t} \\
& +\alpha_{5} \text { LEV }_{t}+\alpha_{6} \text { LOGASSETS }_{t}+\alpha_{7} \text { INVEST }_{t} \\
& +\sum \text { Industry }+\sum \text { Year }+\epsilon_{t+1}
\end{aligned}
$$

where $M B, R O A, L E V$ are defined above. $C A S H$ is cash and cash equivalents divided by lagged total assets. $A G E$ is the natural log of firm age plus one, where firm age is calculated as the current fiscal year minus the first year when a firm appears on COMPUSTAT. LOGASSETS is the natural log of total assets. INVEST is the sum of capital expenditures, research and development expense, and acquisitions less proceeds from sale of fixed assets and depreciation, divided by lagged total assets.

Payout Total cash dividends paid divided by lagged total assets

Free_CF Cash flow from operation minus cash dividends, scaled by lagged total assets

$R O A \_S T D \quad$ The standard deviation of $R O A$ for the past three years 
Figure 1: Distribution of votes

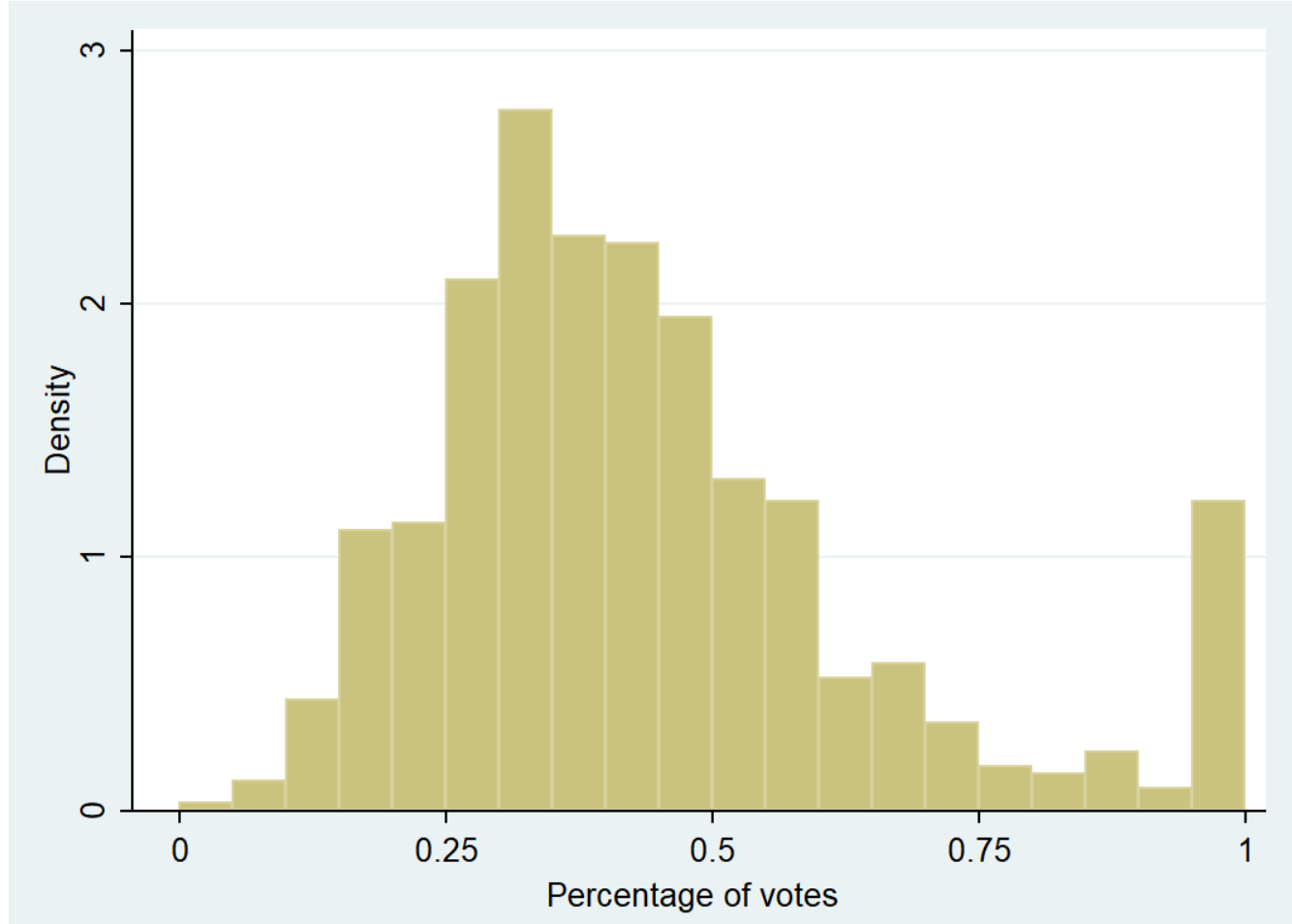

Notes. This figure plots a histogram of the distribution of the number of elections with the percentage of votes for unionizing in our sample across 20 equally spaced bins (with a 5.0\% bin width). Union election results are from the NLRB over 1980-2015. 
Figure 2: Density of union vote shares

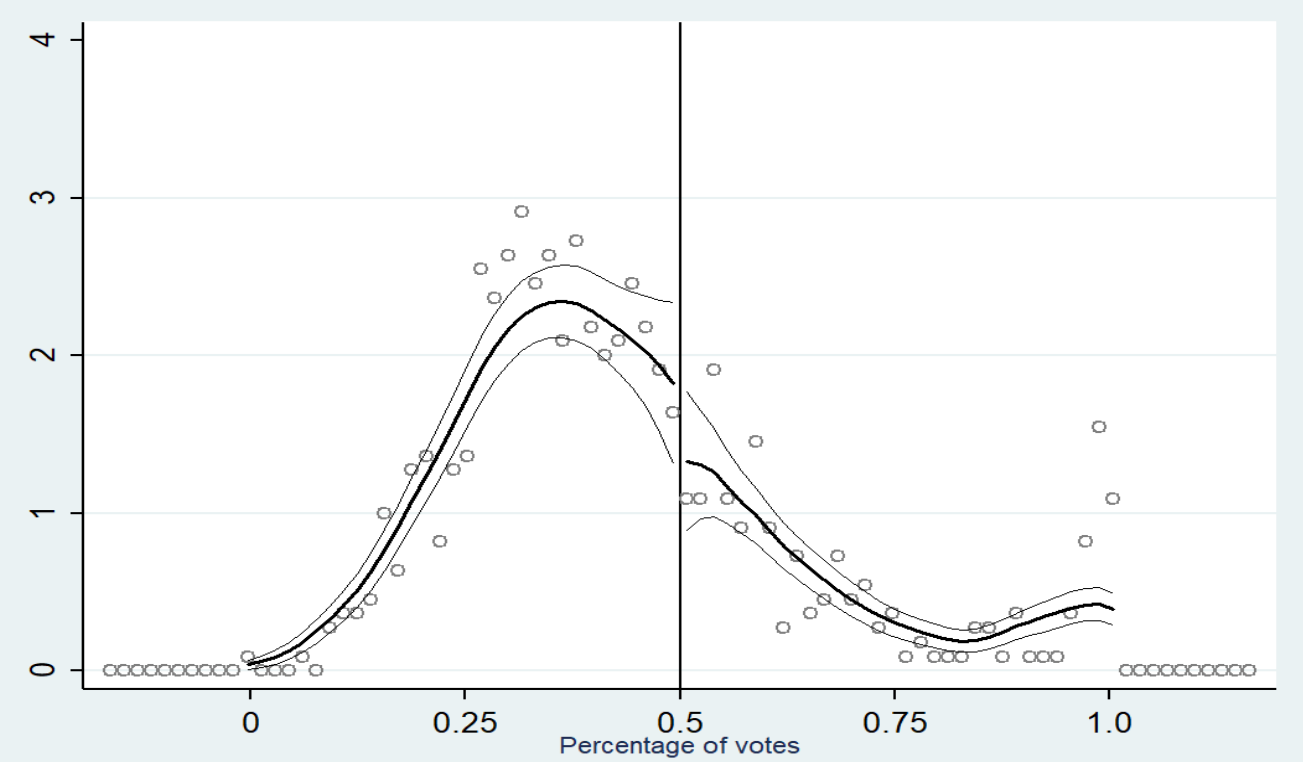

Notes. This figure plots the density of union vote shares following the procedure in McCrary (2008). The $x$ axis is the percentage of votes favoring unionization. The dots depict the density estimate. The solid line represents the fitted density function of the forcing variable (the number of vote shares) with a $95 \%$ confidence interval around the fitted line. Union election results are from the NLRB over 1980-2015. 
Figure 3: Regression discontinuity plots
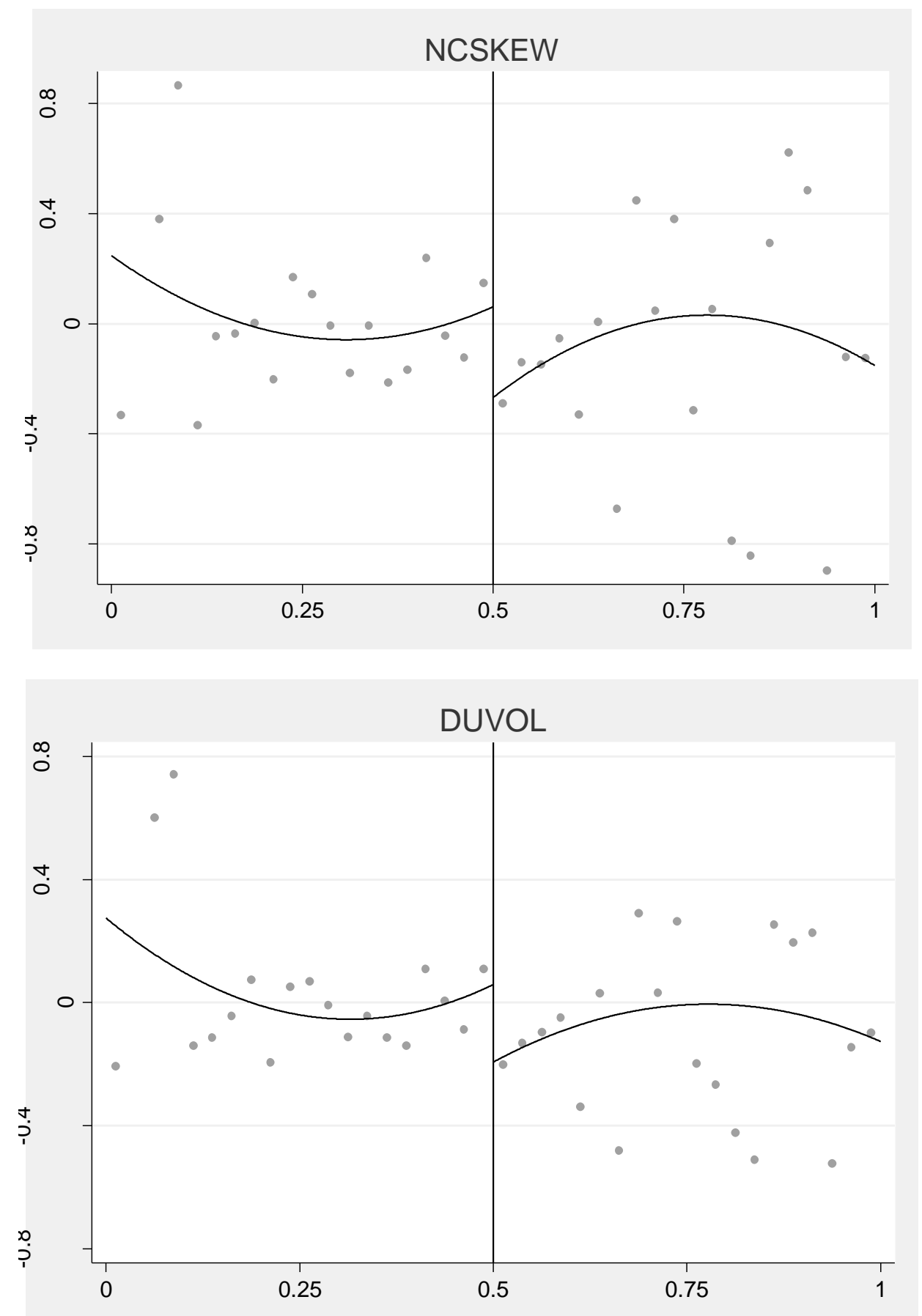

Notes. This figure presents regression discontinuity plots using a fitted quadratic polynomial estimate with $95 \%$ confidence intervals. The $x$ axis is the percentage of votes favoring unionization and the dots depict the average crash risk variables in each of 20 equally spaced bins (with a 5.0\% bin width). Union election results are from the NLRB over 1980-2015. Crash risk variables (NCSKEW and DUVOL) are calculated from CRSP over 1981-2016. 
Table 1: Descriptive statistics

\begin{tabular}{|c|c|c|c|c|c|c|}
\hline & $\mathrm{N}$ & MEAN & $\mathrm{SD}$ & $\mathrm{P} 25$ & $\mathrm{P} 50$ & P75 \\
\hline \multicolumn{7}{|c|}{ Crash risk statistics } \\
\hline NCSKEW & 687 & -0.048 & 0.702 & -0.439 & -0.098 & 0.334 \\
\hline$D U V O L$ & 687 & -0.042 & 0.476 & -0.376 & -0.061 & 0.259 \\
\hline \multicolumn{7}{|c|}{ Union election statistics } \\
\hline Unionization & 687 & 0.291 & 0.455 & 0.000 & 0.000 & 1.000 \\
\hline VOTE & 687 & 0.442 & 0.210 & 0.303 & 0.400 & 0.536 \\
\hline
\end{tabular}

Notes. This table reports the descriptive statistics of our sample. The sample period is from 1981 through 2016. All variables are defined in Appendix. 
Table 2: Difference in the observable characteristics between unionized and nonunionized firms

\begin{tabular}{lllll}
\hline & Unionization $=0$ & Unionization $=1$ & Difference & $\mathrm{p}$-value \\
\hline ROA & 0.054 & 0.055 & -0.001 & 0.920 \\
$M B$ & 2.019 & 1.853 & 0.166 & 0.662 \\
SIZE & 7.010 & 6.398 & 0.612 & 0.477 \\
LEV & 0.193 & 0.234 & -0.041 & 0.404 \\
DTURN & 0.089 & 0.018 & 0.071 & 0.507 \\
SIGMA & 0.053 & 0.038 & 0.015 & 0.140 \\
RET & -0.215 & -0.089 & -0.126 & 0.191 \\
ABACC & 0.052 & 0.049 & 0.003 & 0.853 \\
\hline
\end{tabular}

Notes. This table presents the differences in observable characteristics between firms that win union elections versus those that lose by a small margin (vote shares within the interval of $[48 \%, 52 \%])$. The sample period is from 1981 through 2016. All variables are defined in Appendix. 
Table 3: Regression discontinuity - Global polynomial

\begin{tabular}{|c|c|c|c|c|c|c|}
\hline & $(1)$ & $(2)$ & (3) & (4) & $(5)$ & $(6)$ \\
\hline & NCSKEW & DUVOL & NCSKEW & $D U V O L$ & NCSKEW & DUVOL \\
\hline \multirow[t]{2}{*}{ Unionization } & $-0.309 * *$ & $-0.227 * *$ & $-0.305^{*} *$ & $-0.242 * *$ & $-0.283^{*}$ & $-0.221 * *$ \\
\hline & $(-2.121)$ & $(-2.311)$ & $(-2.052)$ & $(-2.395)$ & $(-1.914)$ & $(-2.197)$ \\
\hline \multirow[t]{2}{*}{ DVOTE } & 1.125 & 1.096 & 0.513 & 0.848 & 0.278 & 0.680 \\
\hline & $(1.056)$ & $(1.522)$ & $(0.468)$ & $(1.138)$ & $(0.253)$ & $(0.907)$ \\
\hline \multirow[t]{2}{*}{ DVOTE $E^{2}$} & 2.974 & 3.035 & 1.258 & 2.300 & 0.668 & 1.889 \\
\hline & (1.089) & (1.643) & $(0.449)$ & (1.207) & $(0.238)$ & $(0.987)$ \\
\hline \multirow[t]{2}{*}{ Unionization $* D V O T E$} & 0.919 & 0.140 & 1.608 & 0.562 & 1.668 & 0.610 \\
\hline & $(0.545)$ & $(0.123)$ & $(0.935)$ & $(0.480)$ & $(0.971)$ & $(0.521)$ \\
\hline \multirow[t]{2}{*}{ Unionization $* D V O T E^{2}$} & $-6.627 *$ & $-5.278 * *$ & -5.092 & $-4.832 *$ & -3.995 & -4.144 \\
\hline & $(-1.804)$ & $(-2.125)$ & $(-1.359)$ & $(-1.897)$ & $(-1.069)$ & $(-1.629)$ \\
\hline \multirow[t]{2}{*}{ SIZE } & & & & & $0.0343^{*}$ & $0.0237 *$ \\
\hline & & & & & (1.839) & (1.866) \\
\hline \multirow[t]{2}{*}{$L E V$} & & & & & 0.255 & -0.0158 \\
\hline & & & & & $(1.118)$ & $(-0.102)$ \\
\hline \multirow[t]{2}{*}{$M B$} & & & & & 0.0204 & 0.00746 \\
\hline & & & & & $(1.092)$ & $(0.587)$ \\
\hline \multirow[t]{2}{*}{$R O A$} & & & & & $1.303 * *$ & $0.635^{*}$ \\
\hline & & & & & $(2.533)$ & $(1.816)$ \\
\hline \multirow[t]{2}{*}{ DTURN } & & & & & 0.0368 & 0.0689 \\
\hline & & & & & $(0.443)$ & (1.217) \\
\hline \multirow[t]{2}{*}{$R E T$} & & & & & -0.0309 & -0.148 \\
\hline & & & & & $(-0.0579)$ & $(-0.408)$ \\
\hline \multirow[t]{2}{*}{ SIGMA } & & & & & 1.811 & -0.408 \\
\hline & & & & & $(0.418)$ & $(-0.138)$ \\
\hline \multirow[t]{2}{*}{$A B A C C$} & & & & & -0.157 & -0.186 \\
\hline & & & & & $(-0.198)$ & $(-0.345)$ \\
\hline \multirow[t]{2}{*}{$A B A C C^{2}$} & & & & & -1.577 & -0.714 \\
\hline & & & & & $(-0.901)$ & $(-0.599)$ \\
\hline \multirow{2}{*}{ Constant } & 0.0502 & 0.0464 & 0.180 & 0.104 & -0.281 & -0.0880 \\
\hline & $(0.552)$ & $(0.755)$ & (1.294) & (1.098) & $(-1.123)$ & $(-0.516)$ \\
\hline Polynomial & 2 & 2 & 2 & 2 & 2 & 2 \\
\hline Year FE & No & No & Yes & Yes & Yes & Yes \\
\hline Industry FE & No & No & Yes & Yes & Yes & Yes \\
\hline Observations & 687 & 687 & 687 & 687 & 687 & 687 \\
\hline
\end{tabular}

Notes. This table shows the RDD results from estimating a polynomial model specified in Equation (4). DVOTE is defined as VOTE minus 0.5. The sample period is from 1981 through 2016. All variables are defined in Appendix. *, **, and *** represent statistical significance at the $10 \%, 5 \%$, and $1 \%$ levels, respectively. 
Table 4: Regression discontinuity - Nonparametric local linear regression

\begin{tabular}{lllll}
\hline & \multicolumn{2}{c}{ Triangular } & \multicolumn{2}{c}{ Rectangular } \\
\cline { 2 - 5 } & \multicolumn{1}{c}{$(1)$} & $(2)$ & $(3)$ & $(4)$ \\
\cline { 2 - 5 } & NCSKEW & DUVOL & NCSKEW & DUVOL \\
\hline Unionization & $-0.301 * *$ & $-0.266^{* * *}$ & $-0.260^{* *}$ & $-0.278^{* *}$ \\
& $(-2.422)$ & $(-2.856)$ & $(-2.137)$ & $(-2.321)$ \\
\hline
\end{tabular}

Notes. This table presents local linear regression results using the optimal bandwidth following Imbens and Kalyanaraman (2012). Results using triangular and rectangular kernels are both reported. The sample period is from 1981 through 2016. All variables are defined in Appendix. *, **, and *** represent statistical significance at the $10 \%$, $5 \%$, and $1 \%$ levels, respectively. 
Table 5: Robustness tests

Panel A: Alternative bandwidths

\begin{tabular}{lll}
\hline & $(1)$ & $(2)$ \\
\hline & NCSKEW & DUVOL \\
\hline Unionization (Optimal bandwidth*0.25) & $-0.661^{* *}$ & $-0.502^{* *}$ \\
& $(-2.517)$ & $(-1.968)$ \\
Unionization (Optimal bandwidth*0.5) & $-0.388^{* *}$ & $-0.371^{* *}$ \\
& $(-2.249)$ & $(-2.278)$ \\
Unionization (Optimal bandwidth*1.5) & $-0.207^{*}$ & $-0.239^{* * *}$ \\
& $(-1.938)$ & $(-3.099)$ \\
Unionization (Optimal bandwidth*2.0) & $-0.170^{*}$ & $-0.176^{* *}$ \\
& $(-1.723)$ & $(-2.263)$ \\
\hline
\end{tabular}

Panel B: Including control variables

\begin{tabular}{lll}
\hline & $(1)$ & $(2)$ \\
\cline { 2 - 3 } & NCSKEW & DUVOL \\
\hline Unionization & $-0.288^{* *}$ & $-0.249^{* *}$ \\
Control variables & $(-2.232)$ & $(-2.248)$ \\
\hline
\end{tabular}

Panel C: Placebo tests

\begin{tabular}{lll}
\hline & $(1)$ & $(2)$ \\
\cline { 2 - 3 } & NCSKEW & DUVOL \\
\hline Unionization (cutoff=25\%) & -0.013 & -0.058 \\
& $(-0.058)$ & $(-0.310)$ \\
Unionization (cutoff=45\%) & -0.151 & -0.109 \\
& $(-0.925)$ & $(-0.896)$ \\
Unionization (cutoff=55\%) & 0.066 & 0.110 \\
& $(0.400)$ & $(0.786)$ \\
Unionization (cutoff=75\%) & -0.572 & -0.405 \\
& $(-1.260)$ & $(-0.982)$ \\
\hline
\end{tabular}

Panel D: Alternative measures of crash risk

\begin{tabular}{lll}
\hline & $(1)$ & $(2)$ \\
\cline { 2 - 3 } & Crash & Down \\
\hline Unionization & $-0.146^{* *}$ & $-0.157 * *$ \\
& $(-2.307)$ & $(-2.092)$
\end{tabular}

Notes. This table reports the robustness tests using the local linear regressions. Results using triangular kernels are reported. Panel A reports the results with the alternative bandwidths. Panel B reports the results including control variables. Panel C reports the placebo tests that artificially assume alternative thresholds other than $50 \%$. Panel D reports the results using alternative measures of crash risk. The sample period is from 1981 through 2016. All variables are defined in Appendix. *, **, and *** represent statistical significance at the $10 \%, 5 \%$, and $1 \%$ levels, respectively. 
Table 6: Subsample analyses based on resource diversion

Panel A: Payout (Payout)

\begin{tabular}{llccc}
\hline & $(1)$ & $(2)$ & $(3)$ & $(4)$ \\
& NCSKEW & DUVOL & NCSKEW & DUVOL \\
\hline \multirow{3}{*}{ Unionization } & High & Low \\
& -0.041 & -0.100 & $-0.712^{* *}$ & $-0.444^{* *}$ \\
& $(-0.208)$ & $(-0.568)$ & $(-2.491)$ & $(-2.461)$ \\
\hline
\end{tabular}

Panel B: Free cash flow (Free_CF)

\begin{tabular}{llllc}
\hline & $(1)$ & $(2)$ & $(3)$ & $(4)$ \\
& NCSKEW & DUVOL & NCSKEW & DUVOL \\
\hline \multirow{3}{*}{ Unionization } & High & Low \\
& $-0.0 .574 * *$ & $-0.377 * *$ & -0.108 & -0.182 \\
& $(-2.25)$ & $(-2.183)$ & $(-0.495)$ & $(-1.263)$ \\
\hline
\end{tabular}

Notes. This table presents local linear regression results of subsample analyses based on resource diversion using the optimal bandwidth following Imbens and Kalyanaraman (2012). Results using triangular kernels are reported. Panel A reports the results partitioned by the sample median of payout (Payout), while Panel B reports the results partitioned by the sample median of free cash flow (Free_CF). The sample period is from 1981 through 2016. All variables are defined in Appendix. *, **, and $* * *$ represent statistical significance at the $10 \%, 5 \%$, and $1 \%$ levels, respectively. 
Table 7: Subsample analyses based on overinvestment (OVERINVEST)

Panel A: Partitioning the full sample

\begin{tabular}{llclc}
\hline & $(1)$ & $(2)$ & $(3)$ & $(4)$ \\
& NCSKEW & DUVOL & NCSKEW & DUVOL \\
\hline \multirow{3}{*}{ Unionization } & High & \multicolumn{2}{c}{ Low } \\
& $-0.518^{* *}$ & $-0.307^{*}$ & -0.264 & -0.246 \\
& $(-2.395)$ & $(-1.900)$ & $(-0.854)$ & $(-1.389)$ \\
\hline
\end{tabular}

Panel B: Partitioning the subsample with positive OVERINVEST

\begin{tabular}{llclc}
\hline & $(1)$ & $(2)$ & $(3)$ & $(4)$ \\
& NCSKEW & DUVOL & NCSKEW & DUVOL \\
\hline \multirow{3}{*}{ Unionization } & High & Low \\
& $-0.997 * *$ & $-0.423 * *$ & -0.288 & -0.225 \\
& $(-2.555)$ & $(-2.019)$ & $(-0.912)$ & $(-0.817)$ \\
\hline
\end{tabular}

Notes. This table presents local linear regression results of subsample analyses based on overinvestment using the optimal bandwidth following Imbens and Kalyanaraman (2012). Results using triangular kernels are reported. Panel A uses the full sample and partitions it by the sample median of OVERINVEST, while Panel B uses the subsample with positive OVERINVEST and partitions it by the sample median of OVERINVEST. The sample period is from 1981 through 2016. All variables are defined in Appendix. $*$, **, and $* * *$ represent statistical significance at the $10 \%, 5 \%$, and $1 \%$ levels, respectively. 
Table 8: Subsample analyses based on risk-taking

Panel A: ROA volatility (ROA_STD)

\begin{tabular}{llclc}
\hline & $(1)$ & $(2)$ & $(3)$ & $(4)$ \\
& NCSKEW & DUVOL & NCSKEW & DUVOL \\
\hline \multirow{3}{*}{ Unionization } & High & Low \\
& $-0.705^{*}$ & $-0.573 * * *$ & -0.352 & -0.176 \\
& $(-1.962)$ & $(-3.052)$ & $(-1.444)$ & $(-1.044)$ \\
\hline
\end{tabular}

Panel B: Leverage ( $L E V)$

\begin{tabular}{llclc}
\hline & $(1)$ & $(2)$ & $(3)$ & $(4)$ \\
& NCSKEW & DUVOL & NCSKEW & DUVOL \\
\hline \multirow{3}{*}{ Unionization } & High & Low \\
& $-1.328 * * *$ & $-0.903 * * *$ & 0.024 & 0.052 \\
& $(-3.540)$ & $(-4.333)$ & $(0.126)$ & $(0.300)$ \\
\hline
\end{tabular}

Notes. This table presents local linear regression results of subsample analyses based on risk-taking using the optimal bandwidth following Imbens and Kalyanaraman (2012). Results using triangular kernels are reported. Panel A reports the results partitioned by the sample median of ROA volatility (ROA_STD), while Panel B reports the results partitioned by the sample median of leverage $(L E V)$. The sample period is from 1981 through 2016. All variables are defined in Appendix. *, **, and *** represent statistical significance at the $10 \%, 5 \%$, and $1 \%$ levels, respectively. 
Table 9: Subsample analyses based on opacity

Panel A: Total accruals $(T A)$

\begin{tabular}{llclc}
\hline & $(1)$ & $(2)$ & $(3)$ & $(4)$ \\
& NCSKEW & DUVOL & NCSKEW & DUVOL \\
\hline \multirow{3}{*}{ Unionization } & High & Low \\
& $-0.639 * *$ & $-0.364^{* *}$ & -0.141 & -0.188 \\
& $(-2.556)$ & $(-2.449)$ & $(-0.633)$ & $(-1.031)$ \\
\hline
\end{tabular}

Panel B: Analyst coverage (Analyst_COV)

\begin{tabular}{llccc}
\hline & $(1)$ & $(2)$ & $(3)$ & $(4)$ \\
& $N C S K E W$ & DUVOL & NCSKEW & DUVOL \\
\hline \multirow{3}{*}{ Unionization } & High & Low \\
& -0.148 & 0.035 & $-0.510^{*}$ & $-0.396^{* *}$ \\
& $(-0.668)$ & $(0.206)$ & $(-1.730)$ & $(-2.311)$ \\
\hline
\end{tabular}

Notes. This table presents local linear regression results of subsample analyses based on opacity using the optimal bandwidth following Imbens and Kalyanaraman (2012). Results using triangular kernels are reported. Panel A reports the results for firms with high total accruals versus those with low total accruals, while Panel B reports the results for firms with high analyst coverage versus those with low analyst coverage. The sample period is from 1981 through 2016. All variables are defined in Appendix. *, **, and $* * *$ represent statistical significance at the $10 \%, 5 \%$, and $1 \%$ levels, respectively. 
Table 10: Right-to-work laws

\begin{tabular}{lllll}
\hline & $(1)$ & $(2)$ & $(3)$ & $(4)$ \\
& NCSKEW & DUVOL & NCSKEW & DUVOL \\
\hline \multirow{3}{*}{ Unionization } & \multicolumn{2}{l}{ With right-to-work laws } & \multicolumn{2}{l}{ Without right-to-work laws } \\
& -0.404 & -0.149 & $-0.412^{*}$ & $-0.410^{* *}$ \\
& $(-1.179)$ & $(-0.771)$ & $(-1.720)$ & $(-2.382)$ \\
\hline
\end{tabular}

Notes. This table presents local linear regression results using the optimal bandwidth following Imbens and Kalyanaraman (2012) for firms located in the states with rightto-work laws versus the states without right-to-work laws. Results using triangular kernels are reported. The sample period is from 1981 through 2016. All variables are defined in Appendix. * $* *$, and $* * *$ represent statistical significance at the $10 \%, 5 \%$, and $1 \%$ levels, respectively. 
Table 11: Subsample analyses based on performance $(R O A)$

\begin{tabular}{llclc}
\hline & $(1)$ & $(2)$ & $(3)$ & $(4)$ \\
& NCSKEW & DUVOL & NCSKEW & DUVOL \\
\hline \multirow{3}{*}{ Unionization } & High & Low \\
& -0.353 & -0.148 & $-0.548 * *$ & $-0.502 * * *$ \\
& $(-1.421)$ & $(-0.801)$ & $(-2.356)$ & $(-2.943)$ \\
\hline
\end{tabular}

Notes. This table presents local linear regression results of subsample analyses based on performance using the optimal bandwidth following Imbens and Kalyanaraman (2012). Results using triangular kernels are reported. The sample period is from 1981 through 2016. All variables are defined in Appendix. *, **, and *** represent statistical significance at the $10 \%, 5 \%$, and $1 \%$ levels, respectively. 